\title{
The Wolf Site (41SM195), Smith County, Texas
}

Mark Walters

Heritage Research Center, Stephen F. Austin State University

Phil Dering

Follow this and additional works at: https://scholarworks.sfasu.edu/ita

Part of the American Material Culture Commons, Archaeological Anthropology Commons, Environmental Studies Commons, Other American Studies Commons, Other Arts and Humanities Commons, Other History of Art, Architecture, and Archaeology Commons, and the United States History Commons

Tell us how this article helped you.

This Article is brought to you for free and open access by the Center for Regional Heritage Research at SFA ScholarWorks. It has been accepted for inclusion in Index of Texas Archaeology: Open Access Gray Literature from the Lone Star State by an authorized editor of SFA ScholarWorks. For more information, please contact cdsscholarworks@sfasu.edu. 


\section{The Wolf Site (41SM195), Smith County, Texas \\ Creative Commons License \\ (c) (1) (9)}

This work is licensed under a Creative Commons Attribution-NonCommercial 4.0 International License 


\title{
THE WOLF SITE (41SM195), SMITH COUNTY, TEXAS
}

\author{
Mark Walters with a contribution by Phil Dering
}

\section{INTRODUCTION AND SITE HISTORY}

The Wolf site (41SM195) is a prehistoric Caddo site located in eastern Smith County, Texas, in the John Wolf land survey, approximately 12 miles east of Tyler, Texas. This article discusses recent excavations I conducted at the site, and summarizes the archeological findings, including features, the age of the archeological deposits, the various lithic and ceramic artifacts that were recovered, and offers speculations about why this part of Smith County was apparently abandoned by the Caddo peoples in the 15th century.

The Wolf site is an important part of my family's history. The abstract for the property begins with a treaty with Mexico on November $8 \mathrm{th}, 1822$, with the Texas Cherokee. My great-great-grandfather, I. N. Browning, purchased the property on November 18, 1867, and this was part of the 4133 acres he owned in eastern Smith County. My grandfather was born on the property, and in 1950, the property again returned to the family's holdings when my father, J. A. Walters, purchased 1.50 acres of the original tract.

\section{SETTING}

Figure 1 depicts the location of the Wolf site approximately $1.4 \mathrm{~km}$ from the present channel of Auburn Creek, at an elevation of 400 feet amsl. At this point, the Auburn Creek floodplain widens, and a relict channel runs against the upland landform, about $90 \mathrm{~m}$ from the Wolf site. The next lowest landform, at 390 feet amsl, level and closer to water, was not chosen for habitation by the Caddo, although test excavations here (41SM195-A) located a pre-Civil War house site and a buried Woodland period occupation (hopefully, this work will be reported in a future article).

Because of the steep, narrow upper part of the Auburn Creek valley, there arc fcw landforms in and near the floodplain that would have been suitable for human occupation. In fact, there seems to be a trend in Middle Caddo times for sites in this area to be located at considerable distances from water. For example, the Redwine site (41SM 193) is on an upland interstream divide across the creek from the Wolf site (Walters et al. 1998).

At the present time, the active Auburn Creek channel has downcut to sandstone bedrock, probably as a result of historic farming practices, steep gradients, and clay-poor upland sediments, and the floodplain consists of a sandy alluvium. Auburn Creck is in the headwaters of the Harris Creek basin, and this creek drains into the Sabine River, some 20 $\mathrm{km}$ to the north. To the south of the Wolf site, streams flow south and east into the Angelina River drainage.

The portion of the property where the Wolf site is located has been in almost continuous cultivation since the $1860 \mathrm{~s}$, and from 1950-1993, it was used for the cultivation of field-grown roses. Good land management practices, including terracing. were used to keep soil erosion to a minimum. Presently, the site area is used for pasture.

Soils in the vicinity of the site are classified as Lilbert loamy fine sand (Hatherly 1993). These are found on terraces and uplands above drainageways, and formed in 


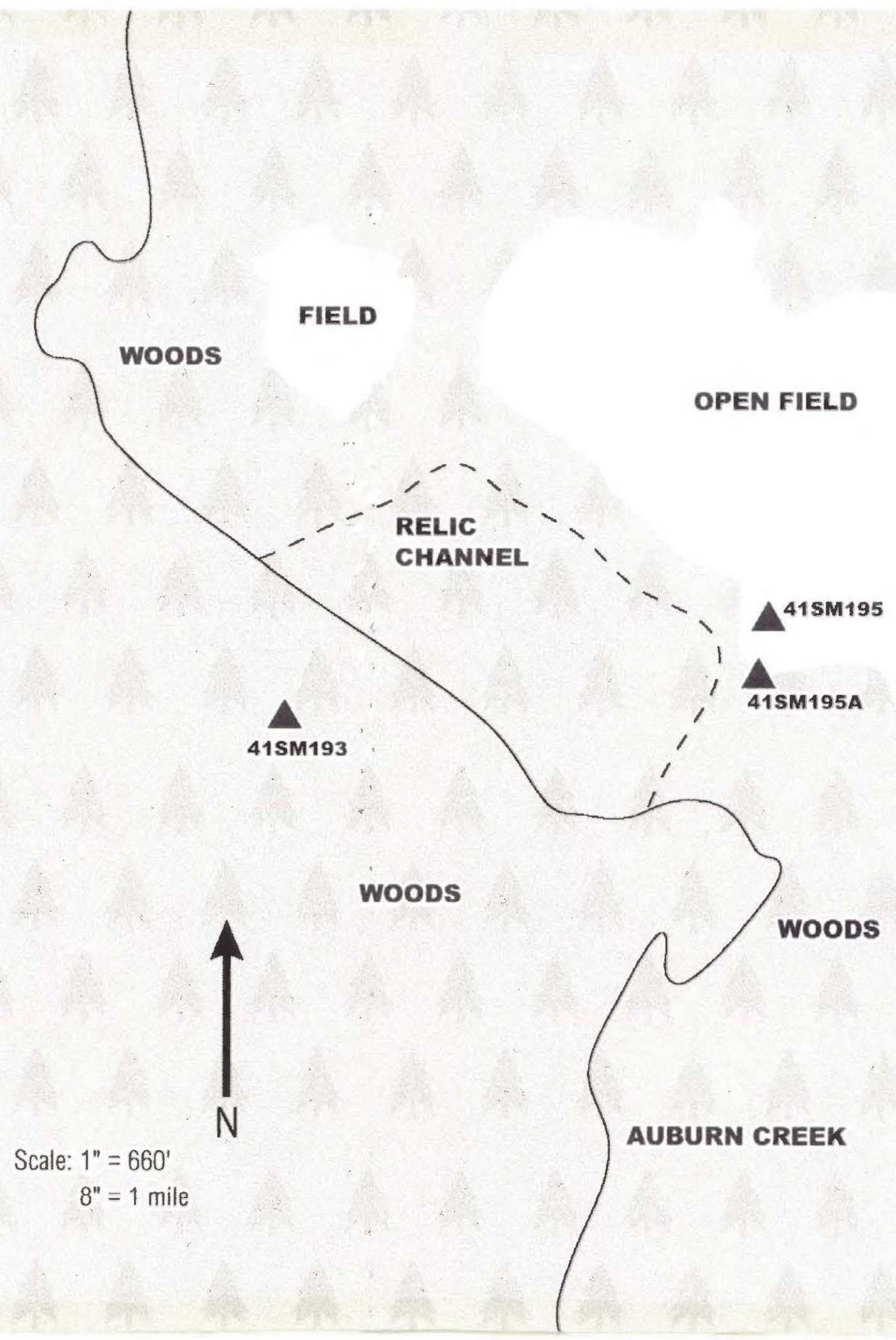

Figure 1. General area of Auburn Creek and the Wolf site (41SM195). 
loamy, unconsolidated sediments under a mixed pine and hardwood forest. The Lilbert soil comprises $5.7 \%$ of the soils in Smith County. The sandy, acid, well-drained nature of the

soil made it conducive to the farming of roses as well as corn and other crops, although the application of fertilizer and lime is needed for insure high yields. Because these soils formed under a forest cover, they have thin and organically-poor A-horizons. Given their sandy, porous, nature in combination with an annual precipitation of 44 inches, soil nutrients are rapidly depleted from the soil.

\section{METHODOLOGY}

Since the $1950 \mathrm{~s}$, the Wolf site has been regularly surface collected, and at one point some years ago, extensive uncontrolled excavations were done here, including using a tractor and a blade. During that work, two circular areas were identified that are interpreted as locations of prehistoric Caddo houses.

For my work, and to determine if intact features or archeological deposits remained at the site, I used a small bulldozer to scrape a 1500 square meter area (Figure 2). Shallow, linear scrapes were made across the site, and $50 \mathrm{~cm}$ wide balks were left between the machine scrapes to provide a measure of vertical control. A 1 × $2 \mathrm{~m}$ unit was also excavated near the center of the site (see below).

The absence of roots, and good soil color contrasts aided in the visual examination of the scraped area. Color abnormalities on the floor of the scraped areas were shovelskimmed and flagged for further investigation, which consisted of bisecting them and looking at the stains in profile to determine if they were cultural, old tree casts, or rodent burrows. During the machine-scraping, the areas that had been excavated some years before, and interpreted as prehistoric Caddo house locations, were identified by dark stains with a mixture of sediments, ash, and charcoal (see Figure 2). These houses were apparently circular and about $6 \mathrm{~m}$ in diameter.

The previous excavations were sufficiently thorough that all sediments had been disturbed as deep as the subsoil, and no features remained for investigation. Two cultural features were identified during the shovel skimming of the machine-scraped area, and these are discussed below.

\section{UNIT 1}

This $1 \times 2 \mathrm{~m}$ unit was begun as part of a field trip/workshop held in conjunction with the 2000 East Texas Archeological Conference to study the Oxidizable Carbon Ratio (OCR) dating technique (see http://members.aol.com/dsfrink/ocr/ocrpage.htm). The first 20 $\mathrm{cm}$ was removed as one level, because it was a plow zone, and remaining levels were 10 $\mathrm{cm}$ in thickness. The sterile clay subsoil was reached at $70 \mathrm{~cm}$ bs (see Figure 2).

The sediments in Unit 1 were screened through 1/4-inch hardware cloth. At the bottom of each level the unit floor was troweled to see if features were present or recognizable, and a plan map was drawn of any visible disturbances or stains. One half of Unit 1 was excavated to $80 \mathrm{~cm}$ bs to provide a better face to study the soil horizons, and a profile of the sediments was drawn of the unit's north wall.

Small numbers of artifacts were recovered in Unit 1 (Table 1). The artifacts and OCR dates from the units suggest that a Caddo occupation was present in the upper $20 \mathrm{~cm}$ of the archeological deposit, with an older Archaic occupation(s) between 20-70 cm bs. 


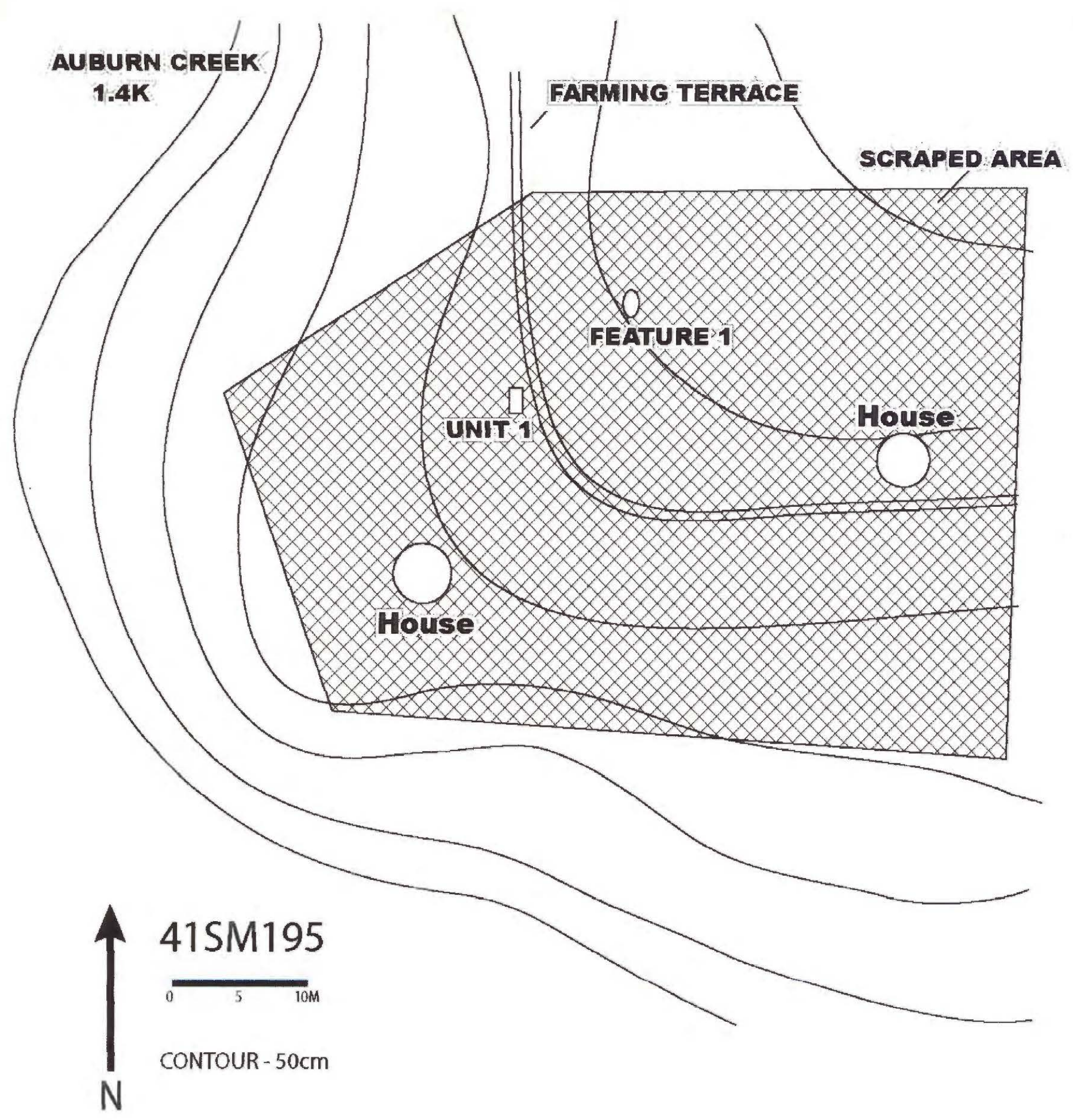

Figure 2. Plan of excavations at the Wolf site (41SM195). 
Table 1. Unit 1 artifacts.

\begin{tabular}{llllll} 
Level & Arrow Point & Tools & Lithic Debris & Plain Sherds & Decorated Sherds \\
& & & & & \\
\hline $0-20 \mathrm{~cm}$ & 1 (fragment) & - & 6 & 7 & 2 (punctated) \\
$20-30 \mathrm{~cm}$ & - & - & 3 & - & - \\
$30-40 \mathrm{~cm}$ & - & 1 (biface) & 2 & - & - \\
$40-50 \mathrm{~cm}$ & - & - & 2 & - & - \\
$50-60 \mathrm{~cm}$ & - & 1 (flake tool) & 9 & - & - \\
$60-70 \mathrm{~cm}$ & - & 3 & - & 2 \\
\hline
\end{tabular}

\section{FEATURE 1}

Feature 1 is a small intact midden deposit $20 \mathrm{~m}$ to the north and between the two previously excavated Caddo houses (see Figure 2). This location halfway between the two houses suggests that they may have been contemporaneous, and the fact that the midden was north of them would have prevented noxious smells from dccaying midden trash reaching the houses because the prevailing south winds would have carried the smell away from the houses.

At $20 \mathrm{~cm}$ bs, below the plow zone, Feature is an oblong $(240 \mathrm{~cm}$ north-south by $160 \mathrm{~cm}$ east-west) area of very dark brown (10YR 3/3) soil with recent linear chisel marks from the use of a parabolic sub-soiler. The north-south feature profile indicates that the maximum depth of Feature 1 was $41 \mathrm{~cm} \mathrm{bs}$, and tapering to more shallow depths at both ends (Figure 3).

The first $20 \mathrm{~cm}$ of the feature had been churned by cultivation, but below that depth (excepting the chisel marks), the featurc fill was a very compact dark brown to very dark brown sandy loam with bone, charcoal, lithic debris, pottery sherds, and burned clay. 'The entire feature matrix was collected for either fine-screening or flotation analysis. Charred floral remains from a Feature 1 flotation sample were analyzed by Phil Dering ('Texas A\&M University, see below) and a sample of charred nutshells was submitted for radiocarbon dating. In addition to the estimated 266 plant remains (weighing $31.5 \mathrm{~g}$ ), the following artifacts were collected from Feature 1: 14 pottery sherds (six plain body, two plain rim, and six decorated body sherds), 458 pieces of lithic debris, one dart point, 424 pieces of fired clay, and 892 small animal bone fragments.

\section{FEATURE 2}

Underlying the northern part of Feature 1 was a $40 \times 50 \mathrm{~cm}$ basin-shaped area of dark brown (10YR 3/3) to dark yellowish-brown (10YR 4/6) soil (Feature 2). The irregularly-shaped basin extended $1 \mathrm{l} \mathrm{cm}$ below the bottom of Feature 1, and extended into the yellowish-red (5YR 5/6) subsoil (Figure 4). The Feature 2 fill was fine-screened, and contained charred plant remains (not submitted for analysis, but included charred wood and nutshells), six pieces of fired clay, one piece of lithic debris, and two small animal bone fragments. 
Journal of Northeast Texas Archaeology, No. 18 (2003)
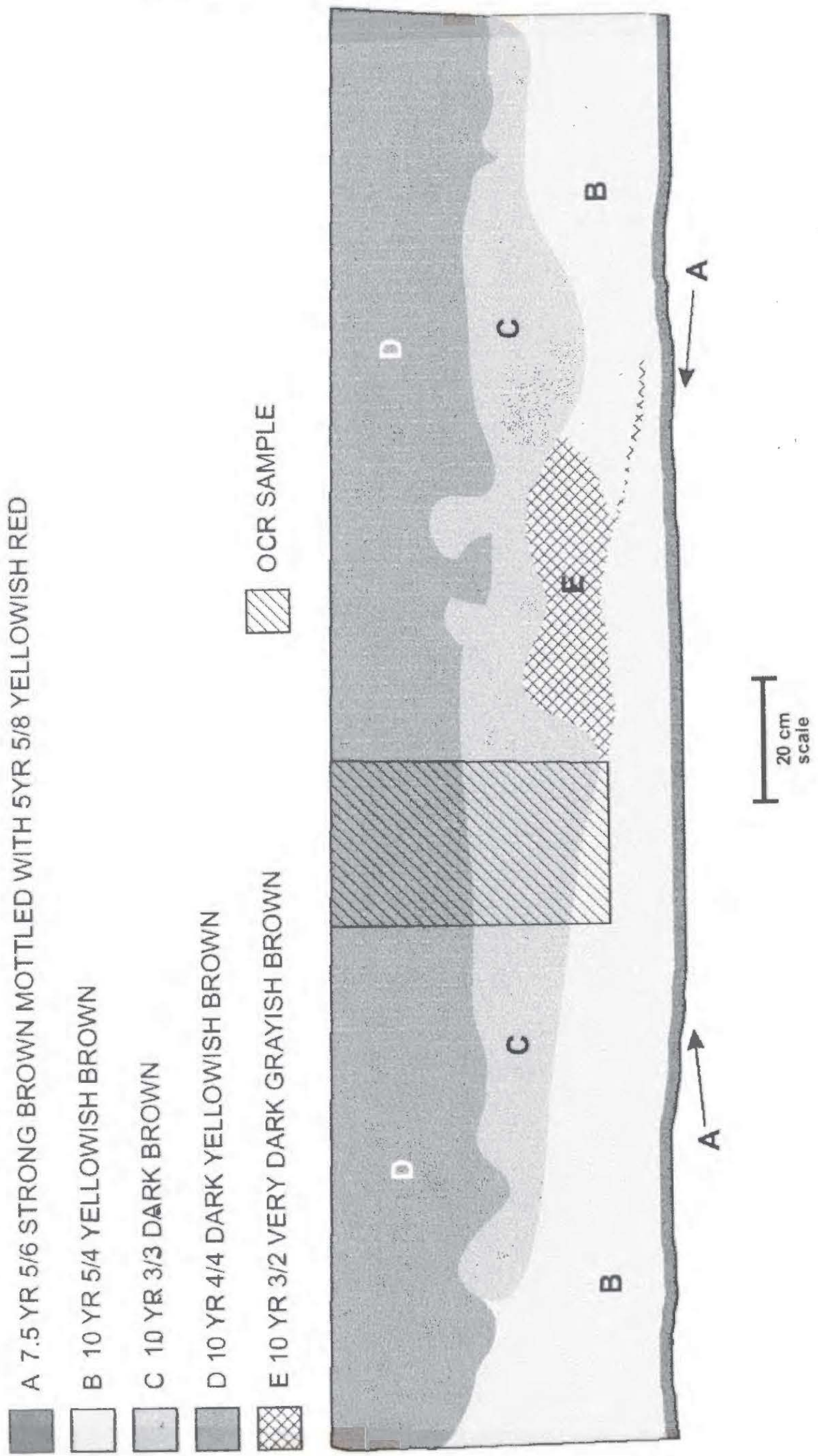

Figure 3. Profile of Feature 1 at the Wolf site (4ISM195). 


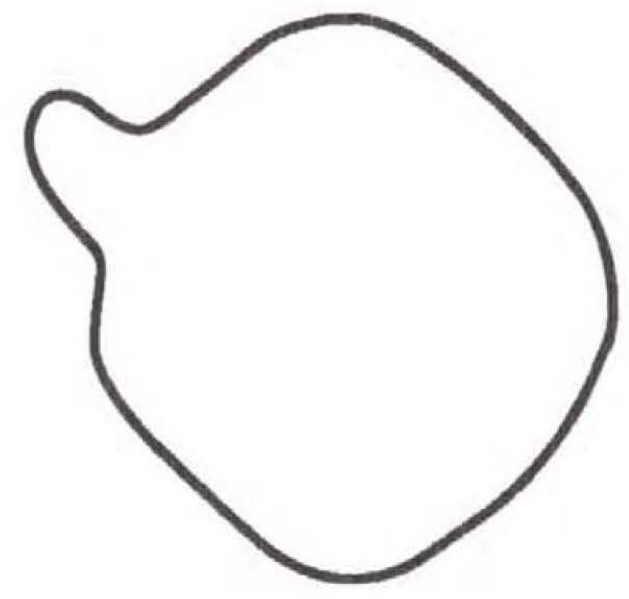

Plain viow at $31 \mathrm{~cm}$ bs

\section{Profile}

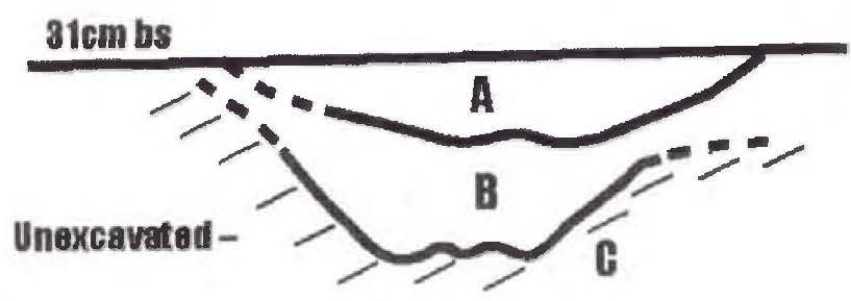

A - 10 YR 3/3 dark brown sandy loam, charcoal flecks

B -10 VR 4/6 dark yellowish -brown sandy loam

$6-5$ YR $5 / 6$ yellowish-red sandy clay

Figure 4. Profile and Plan of Feature 2.

\section{RADIOCARBON AND OCR DATING}

A sample of charred nutshells collected from Feature 1 was submitted for radiocarbon dating by Beta Analytic, Inc. The conventional age of the sample (Beta144827 ) is $530 \pm 40$ B.P. The calibrated intercept is A.D. 1415 , and at two sigma, there is a 95\% probability that the calibrated age of the charred nutshells falls between AD 1315 1350 and AD 1390-1440 (Stuiver et al. 1998; Talma and Vogel 1993). The results were also run using Calib 4.2 (Stuiver et al. 1998), and at 2 sigma, there is a $72.9 \%$ probability that the radiocarbon sample dates from AD 1386-1444.

OCR samples were collected from Unit 1 and Feature 1. The OCR samples from Unit 1 were collected from a column starting in the middle of the plow zone $(12 \mathrm{~cm} \mathrm{bs})$ and continuing at $5 \mathrm{~cm}$ intervals to $70 \mathrm{~cm}$ bs (Table 2). The OCR dates ranged from A.D. 1313 at $12 \mathrm{~cm}$ bs (the zone that contained the Caddo artifacts) to 3775 B.C. in the lowest sediment zone, where artifacts ceased, and the sterile Bt clay horizon was encountered.

Personal communication with Douglas Frink (OCR Dating, Inc.) indicated that there were three levels in the column that had pedogenic marker signatures: a concurrence of fine particle increases, coarse particle increases, and an increase in \% organic carbon. While not all pedogenic markers are indicative of cultural activity, people are certainly a major force in altering landscapes. When these markers occur in association with human artifacts, there is a strong likelihood that the pedogenic markers are cultural in origin. Frink 
Table 2. OCR Dates from Unit 1.

\begin{tabular}{|c|c|c|c|c|c|c|c|c|c|c|c|c|}
\hline Soil Depth & $\mathrm{pH}$ & $\%$ Organic Ca & Ocr Date & Very_Coarse & Coarse & Medium & Fine & Very Fine & Coarse_Silt & Fine_Silt & Sample I Site ld \# & Location \\
\hline 12 & 4.7 & 0.573 & 637 & .36605 & .10959 & .11819 & 1.06258 & 37.92522 & 39.91554 & 20.50283 & $443341-5 M-195$ & $a$ \\
\hline 25 & 5.2 & 0.327 & 1350 & .39734 & .08982 & .06362 & .86329 & 39.12686 & 37.50444 & 21.95463 & 4434 41-SM-195 & a \\
\hline 30 & 5.4 & 0.262 & 2212 & .96991 & .07859 & .04803 & .75472 & 40.92587 & 35.07647 & 22.1464 & $4435 / 41-S M-195$ & a \\
\hline 35 & 5.1 & 0.274 & 3113 & 1.00852 & .08138 & .04002 & .82176 & 42.19366 & 34.19155 & 21.66312 & 4436 41-SM-195 & a \\
\hline 40 & 5.1 & 0.233 & 4084 & .19384 & .07013 & .06285 & .83225 & 41.17838 & 35.32354 & 22.33902 & 4437 41-SM-195 & a \\
\hline 45 & 5.2 & 0.28 & 4718 & .15797 & .10838 & .06021 & .77 & 50.96977 & 25.90176 & 22.0319 & 4438 41-SM-195 & $a$ \\
\hline 50 & 5.3 & 0.282 & 5254 & .22087 & .06416 & .53058 & .76626 & 43.76689 & 31.17234 & 23.47889 & 443941-SM-195 & a \\
\hline 55 & 5.8 & 0.257 & 5893 & .35531 & .06278 & .03657 & .74168 & 47.03606 & 29.55527 & 22.21233 & 4440 $41-$ SM-195 & a \\
\hline 60 & 5.6 & 0.262 & 6723 & .15252 & .11117 & .03796 & .74836 & 49.58345 & 26.90292 & 22.46361 & $4441 / 41-S M-195$ & a \\
\hline 65 & 5.5 & 0.231 & 7147 & .30521 & .07698 & .03646 & .74682 & 49.61612 & 27.39458 & 21.82383 & 4442 41-SM-195 & a \\
\hline 70 & 5.3 & 0.251 & 7675 & .65916 & .09524 & .04799 & .68916 & 53.90811 & 23.54613 & 21.05421 & $4443 \mid 41-S M-195$ & a \\
\hline
\end{tabular}

Table 3. OCR Dates from Feature 1.

\begin{tabular}{|c|c|c|c|c|c|c|c|c|c|c|c|c|c|}
\hline Soil Depth & $\mathrm{pH}$ & \%Organic Ca & Ocr_Date & Very_Coarse & Coarse & Medium & Fine & Very Fine & Coarse_Silt & Fine_Silt & Sample I & Site ld \# & Location \\
\hline 11 & 5.5 & 0.762 & 537 & 1,66295 & .16108 & .11855 & 1.47095 & 38.98174 & 32,4923 & 25.11243 & 4448 & 41SM195 & wolf 2 \\
\hline 19 & 5.7 & 0.771 & 633 & .41349 & .06004 & .08529 & 1.37283 & 39.76283 & 33.79322 & 24.51231 & 4449 & 41 SM195 & wolf 2 \\
\hline 27 & 5.5 & 1,054 & 597 & .23945 & .0922 & .08188 & 1.29357 & 38.00487 & 34.23287 & 26.05516 & 4450 & 41SM195 & wolf 2 \\
\hline 36 & 5.6 & 0.76 & 1475 & .07796 & .11761 & .0625 & 1.20835 & 35.52333 & 35.37749 & 27.63276 & 4451 & 41SM195 & wolf 2 \\
\hline
\end{tabular}


identified three pedogenic markers at A.D. $1313(12 \mathrm{~cm} \mathrm{bs}), 1163$ B.C. (35 cm bs), and 3953 B.C. ( $50 \mathrm{~cm} \mathrm{bs}$ ). He further noted that the pedogenic marker at $35 \mathrm{~cm}$ bs did not include any midden deposits, and thus the cultural materials may represent a short-term occupation or a lithic processing area, instead of an organic-processing habitation area. Artifacts collected from Unit 1, as well as other artifacts collected from the site, agree with this series of OCR dates.

Four OCR samples were collected from Feature 1. The first three samples are from the midden deposits, and range in age from A.D. 1317 to A.D. 1413 at $11 \mathrm{~cm}$ bs (Table 3). This datc may be influenced by recent farming activities. The OCR dates from the midden deposit indicate that it dates to between A.D. 1317-1353.

Comparing the A.D. 1313 date $(12 \mathrm{~cm}$ bs) from Unit 1 with the OCR dates from Feature 1 suggests that the archeological deposits in both areas are contemporaneous. Further supporting the contemporaneity of the two areas is the OCR date of A.D. 1413 from Feature 1, the two sigma radiocarbon age range of AD 1390-1440; two other OCR dates (see Tables 2 and 3) correspond to the two sigma age range of AD 1315-1350.

\section{ARTIFACTS FROM THE WOLF SITE}

A total of 2414 artifacts were recovered from the Wolf site (Table 4 ). These are from surface contexts, previous collections, Unit 1, and Features 1 and 2.

Table 4. Artifact inventory from the Wolf site (41SM195).

\begin{tabular}{|c|c|c|}
\hline Artifact Category & No. & Percent \\
\hline Pottery & . & \\
\hline $\begin{array}{l}\text { decorated body sherd } \\
\text { decorated rim sherd } \\
\text { plain body sherd } \\
\text { plain rim sherd } \\
\text { base sherd }\end{array}$ & $\begin{array}{l}98 \\
7 \\
231 \\
8 \\
10\end{array}$ & $\begin{array}{l}27.7 \\
2.0 \\
65.2 \\
2.3 \\
2.8\end{array}$ \\
\hline sub-total & 354 & 100.0 \\
\hline \multicolumn{3}{|l|}{ Lithics } \\
\hline $\begin{array}{l}\text { lithic debris } \\
\text { dart points } \\
\text { arrow points } \\
\text { modified flakes } \\
\text { tool fragment } \\
\text { biface fragment } \\
\text { celt/celt fragment } \\
\text { groundstone tool } \\
\text { fire cracked-rock }\end{array}$ & $\begin{array}{l}691 \\
16 \\
6 \\
5 \\
1 \\
5 \\
2 \\
8 \\
1\end{array}$ & $\begin{array}{l}94.1 \\
2.2 \\
0.8 \\
0.7 \\
0.1 \\
0.7 \\
0.3 \\
1.1 \\
0.1\end{array}$ \\
\hline sub-total & 735 & 100.1 \\
\hline
\end{tabular}


Table 4. Artifact inventory from the Wolf site (41SM195), cont.

\begin{tabular}{lll}
\hline Artifact Category & No. & Percent \\
\hline Animal Bone & 894 \\
Fired Clay & 431 \\
\hline & Total artifacts & 2414 \\
\hline
\end{tabular}

\section{Pottery Analysis}

The 354 pottery sherds include 105 decorated sherds, including seven rims (see Table 4). Not including the 10 base sherds, the plain/decorated sherd ratio is 2.28 .

The average thickness for the plain sherds is $7.38 \mathrm{~mm}$, compared to $6.38 \mathrm{~mm}$ for the decorated sherds; the bases average $11.35 \mathrm{~mm}$ in thickness. In terms of firing condition, $8.8 \%$ of the sherds are from vessels fired in a reducing environment, and another $53 \%$ had been fired in a reducing environment and cooled in a high oxygen atmosphere. Only $23.4 \%$ of the sherds were from vessels that were incompletely oxidized, while $14.7 \%$ had been oxidized during firing.

The vast majority of the Wolf site sherds are tempered with grog (46.9\%) and crushed bone-grog $(46.6 \%)$ (Table 5). The decorated vessel sherds are more likely to have been tempered with grog $(52.4 \%)$ than are the plain sherds, as more than $50.6 \%$ of the plain sherds are tempered with bone and grog, compared to $37.1 \%$ of the decorated sherds.

Table 5. Temper analysis, Wolf site sherds.

\begin{tabular}{llllll}
\hline Type & Grog & Bone-grog & Grog-grit* & Bone-grog-grit & N \\
\hline & & & & \\
decorated & $55 / 52.4 \%$ & $39 / 37.1 \%$ & $8 / 7.6 \%$ & $3 / 2.9 \%$ & 105 \\
plain & $111 / 44.6 \%$ & $126 / 50.6 \%$ & $7 / 2.8 \%$ & $5 / 2.0 \%$ & 249 \\
\hline & & & & \\
\hline
\end{tabular}


Table 6. Decorated sherds from the Wolf site.

\begin{tabular}{llllll} 
Type & No. & Punctated & Engraved & Incised & Punctated/Incised \\
\hline Body & 98 & $54 / 55.1 \%$ & $29 / 29.6 \%$ & $12 / 12.2 \%$ & $3 / 3.1 \%$ \\
Rim & 7 & $1 / 14.3 \%$ & $2 / 28.5 \%$ & $3 / 43.0 \%$ & $1 / 14.3 \%$ \\
Total & 105 & $55 / 52.4 \%$ & $31 / 29.5 \%$ & $15 / 14.3 \%$ & $4 / 3.8 \%$ \\
\hline
\end{tabular}

Figure 5. Incised and Punctated sherds.
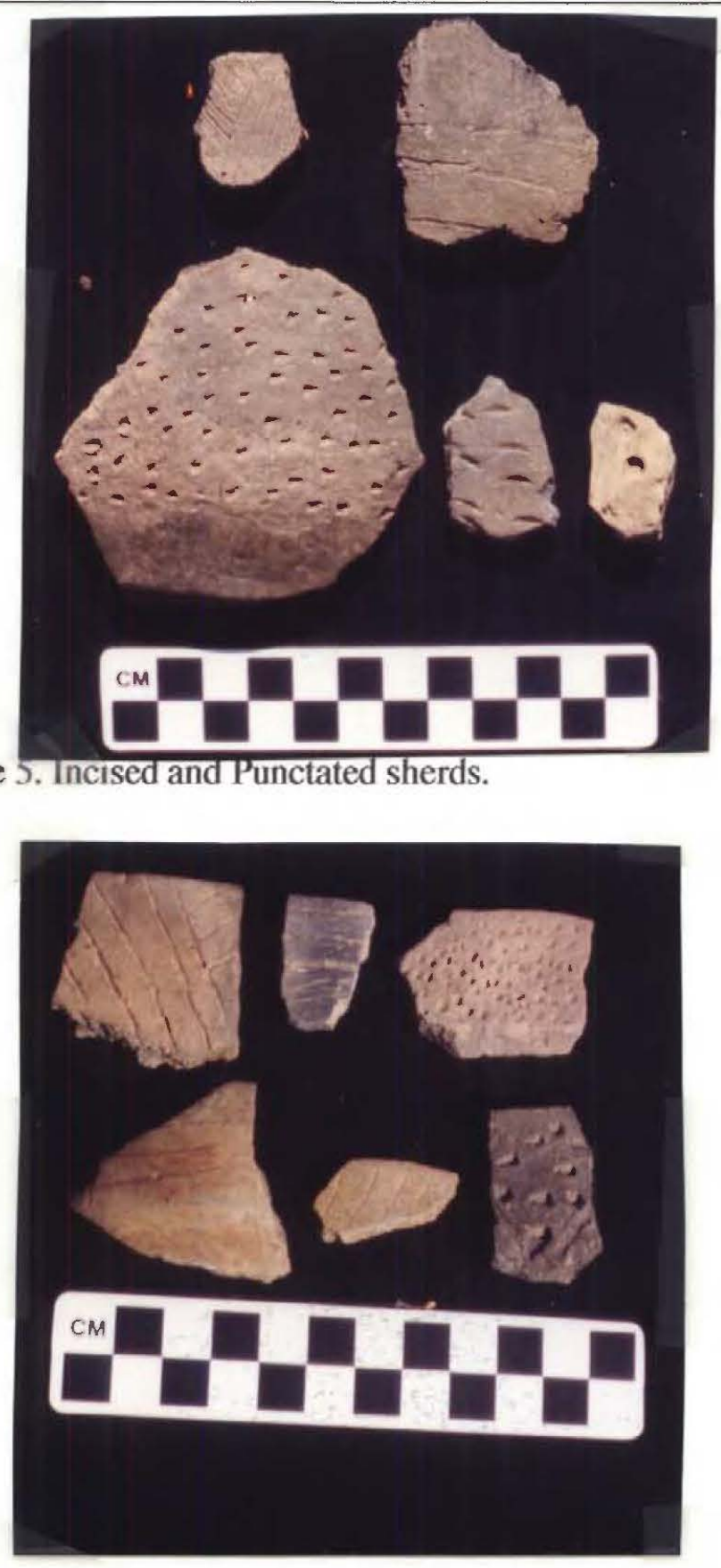

Figure 6. Incised, Punctated, and Incised-Punctated sherds. 
Engraving is the second most numerous decoration in the Wolf site sherds. Of the two engraved rims, one is from a carinated bowl (Figure 7, no. 4) that has a thinned and rounded lip. Below the lip to the point of the carination are parallel horizontal lines that contained red pigment. The temper of the rim is bone-grog, and the sherd is from a vessel that had been fired in a reducing environment. The second engraved rim has a crosshatched design that extends to a thinned and flat lip. It has grog-grit temper, and the vessel had been fired in an oxidizing atmosphere, resulting in a uniformly light brown core. The sherd is $7.5 \mathrm{~mm}$ thick.

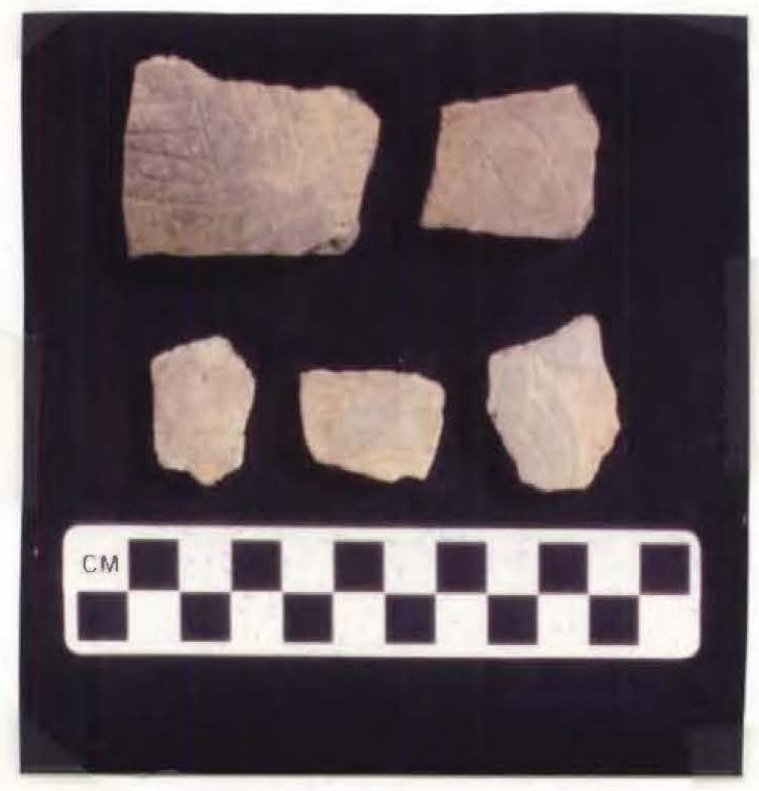

Figure 7. Engraved sherds.

The 29 engraved body sherds in exterior color are mainly light brown $(n=12)$ and brown $(n=11)$, and the others are reddish-brown $(n=3)$, black $(n=1)$, dark brown $(n=1)$, and dark grayish-brown $(\mathrm{n}=1)$ in color. Thirteen have parallel straight lines; six have single straight lines, one bordering an excised area; five have parallel curvilinear lines; and five have opposed straight lines, one enclosing a nested excised triangle. Excised triangles are characteristic of Holly Engraved (see Suhm and Jelks 1962), although this sherd from the Wolf site (see Figure 7, no. 5) does not have the fine detail typical of Holly Engraved sherds from the George C. Davis site, and appears to be a crude copy of the type.

Incising is the third most common decorative technique, and the incised sherds include three rims (see Table 6). One rim is straight with a round and thinned lip. It has haphazardly-executed horizontal parallel incised lines. The exterior surface is black, and the vessel had been fired in a reducing atmosphere. The second incised rim has a single horizontal incised line, and is straight or direct in profile, with a round and thinned lip. It is from a vessel fired in an oxidizing atmosphere, and is $8.5 \mathrm{~mm}$ thick. The third incised rim, with a straight rim profile and a round, thinned lip, has been decorated with opposed parallel straight lines that began at the vessel lip (see Figure 6, no. 1). The vessel sherd is brown in color, and had been incompletely oxidized during firing.

The incised body sherds are decorated with parallel straight lines $(n=5)$, straight lines ( $n=3)$, opposing lines $(n=2)$, curvilinear lines $(n=1)$, and cross-hatching $(n=1)$. Sherd colors range from black $(n=3)$ to dark brown $(n=3)$, brown $(n=2)$, and very light brown $(n=4)$ (see Figures 5-6). The average thickness of the 12 incised body sherds is $8.16 \mathrm{~mm}$. 
The final decorative technique represented in the Wolf site sherds is punctatedincised. The only rim is straight and has a thinned flat lip (see Figure 6, no. 6). It is decorated with a zone of instrument punctates separated by diagonal incised lines. The sherd is $10.0 \mathrm{~mm}$ thick and is black in color; the vessel had been fired and cooled in a reducing atmosphere.

The three punctated-incised body sherds have zones of fingernail punctates separated by curvilinear incised lines. Their average thickness is $9.13 \mathrm{~mm}$, indicating these sherds are from relatively large utility vessels.

There are eight plain rim sherds (see Table 4). Seven have straight rim profiles, and one is slightly everted. Six have rounded lips, including two that are thinned, and the other two have flat lips. They average $6.43 \mathrm{~mm}$ in thickness. Five had been fired in a reducing atmosphere, including two that were cooled in a high oxygen environment. The remaining three plain rims were fired in an oxidizing atmosphere.

Nine of the 10 base sherds are flat and have bone-grog temper; they average 11.35 $\mathrm{mm}$ in thickness. The $10^{\text {th }}$ base sherd has a convex base and bone-grog- and grit temper. Caddo pottery in general is characterized by thick and flat bases, and the prevalence of bone temper in the Wolf site base sherds suggestions that additional bone may have been purposefully added to the vessel base to strengthen the vessels or allow them to be fired longer. However, other ceramic studies suggest that less heat is needed to bring bonetempered pottery to a successful firing temperature (see Rolingson 1998:26). Another possibility is that since the vessel base was often constructed separately from the rest of the vessel-and because of problems caused by low firing temperatures-different temper combinations were used in the bases to compensate for this weakness in firing conditions.

When I look at the Wolf site ceramics, I see a utilitarian pottery assemblage. Compared to other Middle Caddo period sites in Northeast Texas (and in the Sabine River basin) that are marked by an explosion of pottery expression in the decorated pottery, the Wolf site decorated sherd assemblage is a pale reflection of those sites. The design elements here include simple engraved lines, punctations, incised lines, and a few examples of combined decorative elements (i.e., incised-punctated); there are no brushed sherds, no appliqued, no lip notched, and no red-slipped decorated sherds. Furthermore, there are no pipe sherds or fragments in the ceramic assemblage.

Comparing the Wolf site with other nearby sites suggests there are some ceramic similarities with $41 \mathrm{RK} 476$, some $16 \mathrm{~km}$ east, where a series of OCR dates from a midden range from AD 1250-1389 (Walters 2001). As with the Wolf site ceramics, the ceramics here seem utilitarian, with little variety in the decorated sherds. Only $5 \%$ of the decorated sherds were brushed, and the plain/decorated sherd ratio is 2.65 . Incised and punctated sherds account for $75 \%$ of the decorated sherds, and the simple engraved sherds represent another $11 \%$.

At 41SM56, about $8 \mathrm{~km}$ from the Wolf site on an adjacent drainage, a large collection of sherds from 1950s investigations by Sam Whiteside has ceramic similarities to the Wolf site. There were no brushed sherds, and the 36 engraved rims had various combinations of parallel lines and four had excised areas similar to Holly Fine Engraved. Two of the engraved sherds had red pigment smeared in the lines. The one radiocarbon date from the site is $580+/-60$ B.P. (Beta-129978), calibrated to AD 1312-1432.

On the other hand, two nearby and contemporaneous (at least based on the few available dates) Middle Caddo sites show several differences in the ceramics from the Wolf site. Both sites, however, have evidence of small mounds covering burned houses, and 
they also have small family cemeteries. The Redwine site (41SM193), directly across Auburn Creek (see Figure 1) from the Wolf site has a wide variety of decorative motifs in the ceramic sherds, including engraved ladders, engraved scrolls, and $30 \%$ brushed sherds; the plain/decorated sherd ratio is 2.35 . The Redwine site component is radiocarbon-dated to between AD 1304-1434 (Walters et al. 1998).

The Hardy site (41SM55) is another nearby mound center; the one calibrated date from the site is AD 1345-1391 (1 sigma). Again there is a wide variety of decorative motifs in the sherds from the site, with $20 \%$ of the decorated sherds being brushed, and the plain/decorated ratio is 1.21 (Walters and Haskins 2000).

If there is any relevance to the ceramic data reported from these five Caddo sites from a relatively small area in Northeast Texas, there appears to be a distinction between mound sites and other non-mound household sites. Perhaps this was a part of a related settlement pattern made up of small households of related individuals and small hamlets (with mounds) with some evidence of social ranking.

\section{Fired Clay}

There are 456 pieces of small, rounded fired clay were collected from the Wolf site, including 424 from Feature 1 and seven from Feature 2 . These thermally altered bits of red clay did not have cane impressions (i.e., daub) or temper inclusions (as with pieces of ceramic coils expected from making pottery), and appeared to have been dumped in the midden area as waste from some unknown heating/baking activity.

\section{Lithic Analysis}

\section{Lithic Tools}

Chipped lithic tools from the Wolf site include arrow points and fragments, dart points and fragments, flake tools, and a celt and celt fragment. All of the arrow points are from the surface or are from earlier collections, except one (a quartzite tip fragment) from Unit 1 (0-20 cm bs) (Figure 8, no. 2).

Two arrow points have square stems (see Figure 8, no. 1 and no. 6), and are made from a brown chert. Another is a Perdiz, flaked only one side (see Figure 8, no. 4), and made from a light brown chert. There is a second contracting stem arrow point (see Figure 9 , no. 5), and it has heavily serrated edges; it is also made from a light brown chert. An arrow point fragment (see Figure 8, no. 3) is made from red quartzite.

Dart points also are from surface contexts or older collections, other than one from Feature 1 (Figure 9, no. 2). This dart point had an expanding stem and was made from a brown quartzite. Five other expanding stem dart points are made from red quartzite $(n=3)$, petrified wood $(n=1)$, and gray chert; this point also had beveled edges (Figure 9, no. 4). Two Yarbrough-like points were made from gray and brown quartzite (Figure 9, nos. 5-6).

Other dart points from the Wolf site include two Wells points made from red and gray quartzite (Figure 10, nos. 1-2), while another (made from brown chert) is heavily retouched with cortex on the base (Figure 10, no. 3); it is probably a Gary point. The remaining three have square stems and are probably Yarbrough points (Figure 10, no. 46). They are made from red $(n=1)$ and gray $(n=2)$ quartzite. 


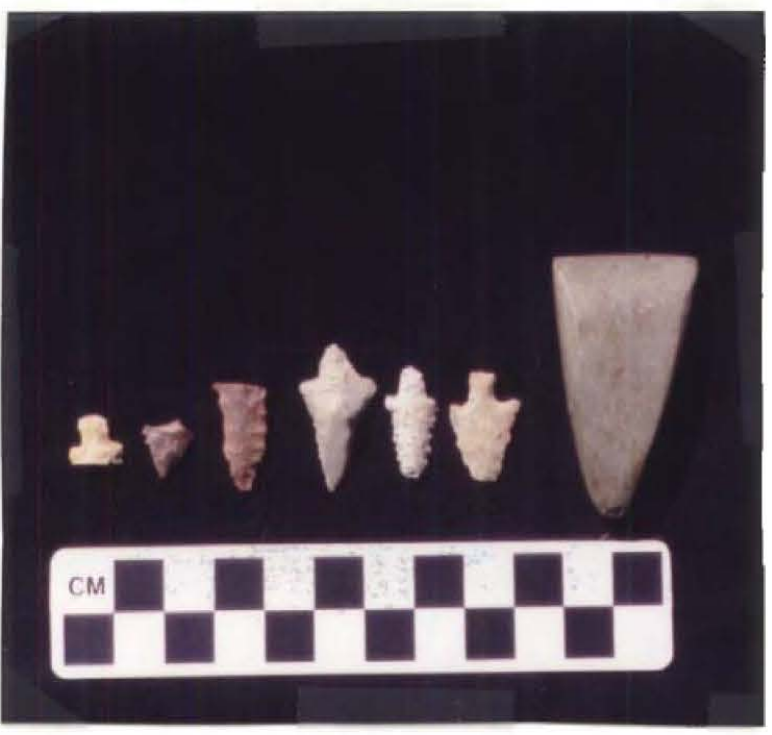

Figure 8. Arrow points and celt from the Wolf site.

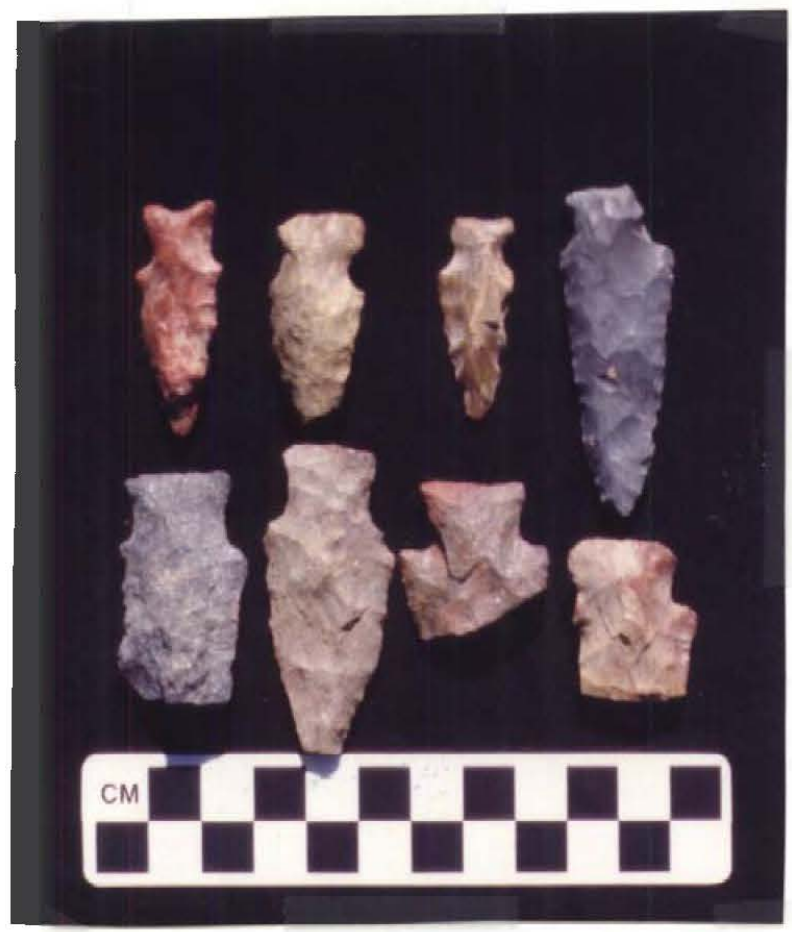

Figure 9. Expanding stem dart points.

Other bifacial tools include a large tip of red quartzite (Unit 1, 30-40 cm bs), and four biface fragments found on the surface. Two of these tool fragments are made from red quartzite, a third is on a brown quartzite, and the last fragment is made from gray chert.

Five expedient flake tools were collected from the surface of the Wolf site. These tools have edge retouching/use-worn areas, and are made from gray chert $(\mathrm{n}=4)$ and red chert $(n=1)$. One of the gray chert flake tools is a large flake $(50 \times 20 \mathrm{~mm})$ found in Unit 1 $(50-60 \mathrm{~cm} \mathrm{bs})$ with retouching on one tool edge. 


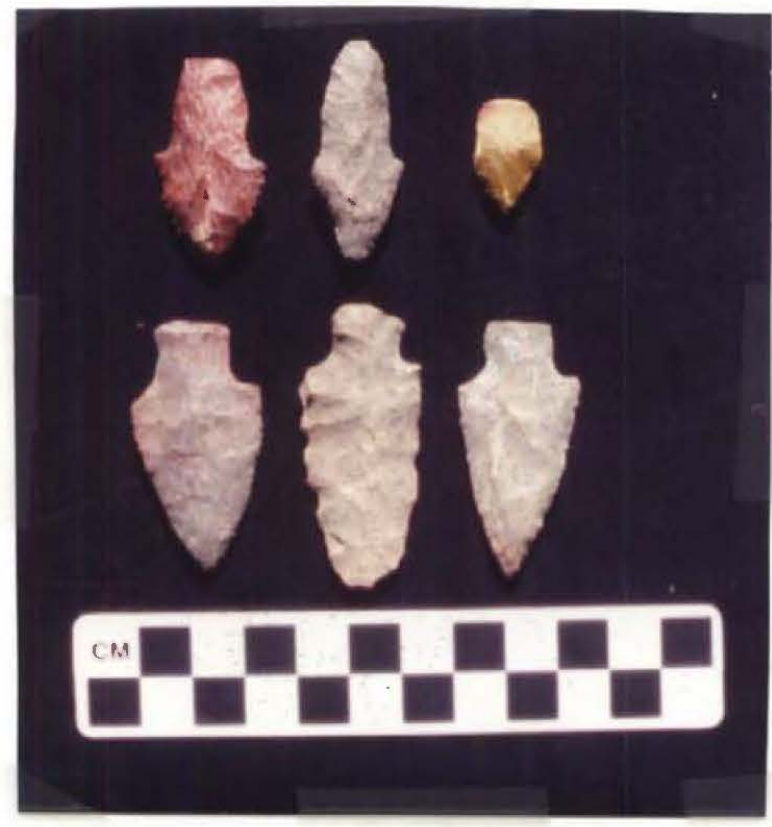

Figure 10. Wells, Yarbrough, and possible Gary point.

\section{Groundstone Tools}

Two of the groundstone tools are chipped and polished celts (see Figure 8, no. 7), including one celt fragment found on the surface. Other groundstone tools were found during the scraping activities. One is a large $(230 \times 190 \times 60 \mathrm{~mm})$ ferruginous sandstone metate or milling stone, with concave grinding surfaces on both faces (Figure 11). The bottom left corner of this tool is beveled and smoothed more than the remainder of the grinding surface. Another ferruginous sandstone grinding implement has a shallow and concave grinding surface on one side (Figure 12, no. 4).

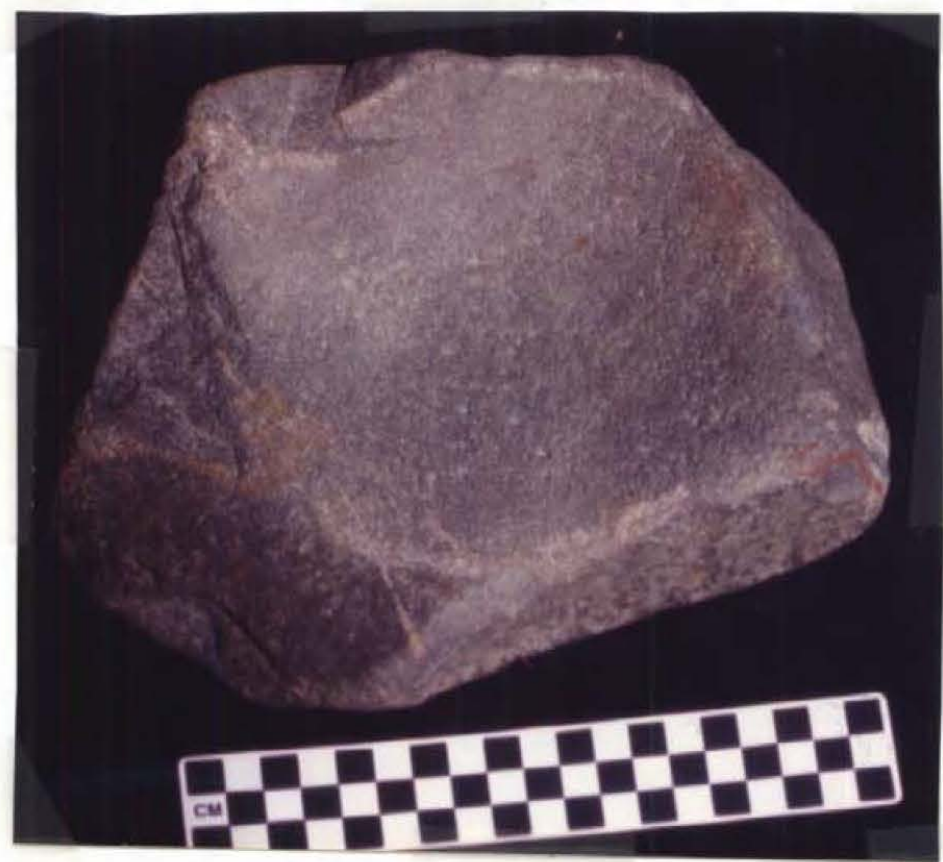

Figure 11. Metate from the Wolf site. 


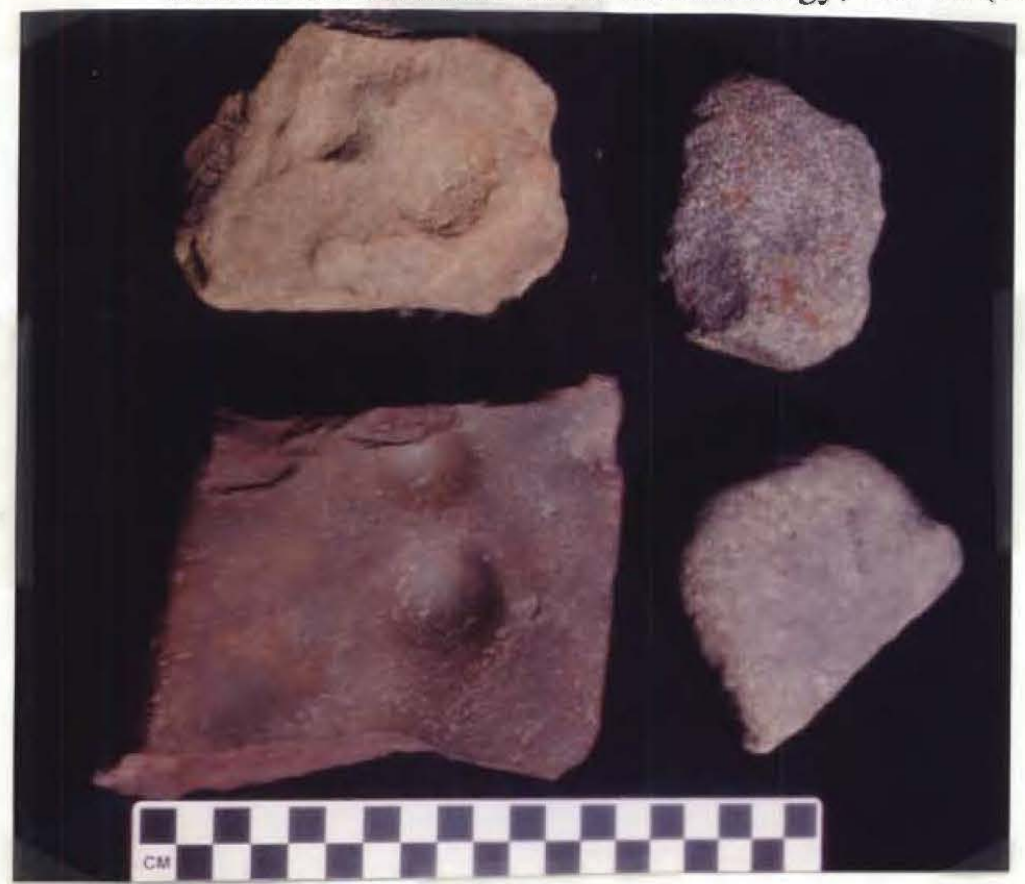

Figure 12. Nutting stones and grinding stone.

There are three nutting stones in the groundstone tool collection (see Figure 12, no. 1-3); two of the three are made on a ferruginous sandstone, and the third is made on a yellowish-brown sandstone (see Figure 12, no. 1). This nutting stone has two roughly pecked convex and circular holes on one face. The first of the ferruginous sandstone nutting stones has a shallow and concave hole on one face and two small $(10 \mathrm{~mm}$ in diameter) pecked holes on the opposite face. The second ferruginous sandstone nutting stone has a shallow and concave grinding area on one face, and the other face is smoothed, with two well-polished, circular, and concave indentations (see Figure 12, no. 3).

\section{Fire-cracked rock}

One fire-cracked rock of the local coarse-grained sandstone was collected from Feature 1. It weighed 33.0 grams.

\section{Lithic Debris}

There are 691 pieces of lithic debris, and $61 \%(n=420)$ are less than $2.5 \mathrm{~mm}$ in size, including 416 of the 458 pieces from Feature 1 . This suggests that tool production/maintenance activities probably took place on mats or the like which were shaken out at the trash dump/midden, as the mats trapped precious stone materials and flakes in this lithic-poor region. Another $8 \%(\mathrm{n}=53)$ are $5 \mathrm{~mm}$ or smaller in diameter; $22 \%$ $(n=156)$ are $10 \mathrm{~mm}$ or smaller; $7.5 \%(n=52)$ are $20 \mathrm{~mm}$ or smaller; and $1.4 \%(n=10)$ are $25 \mathrm{~mm}$ or larger in size. About $8 \%(\mathrm{n}=55)$ of the lithic debris has cortex, and the high percentage of non-cortical flakes $(91 \%)$ indicates that knapping at the Wolf site primarily involved tool maintenance and production from procured flakes, rather than from raw material (or core) reduction.

The lithic debris is almost equally divided between various colors of chert (mainly gray and red) and quartzite (red and grays) (Table 7). Cherts comprise $53 \%$ of the lithic debris, particularly the gray chert. Only $1.7 \%$ of the lithic debris is petrified wood, which is the only locally available source of material. There are Pleistocene gravel deposits some 
$40 \mathrm{~km}$ east on the Red River that have fist-sized and smaller, but workable chert cobbles, but most of the cherts noted in those gravel beds probably have been moved a considerable distance before they ended up in the Sabine River gravels.

Table 7. Lithic debris raw material.

\begin{tabular}{|c|c|c|c|c|}
\hline $\begin{array}{l}\text { Raw Materials/: } \\
\text { Colors }\end{array}$ & Cherts & Quartzite & $\begin{array}{l}\text { Petrified } \\
\text { Wood }\end{array}$ & Quartz \\
\hline $\begin{array}{l}\text { red } \\
\text { gray } \\
\text { light brown } \\
\text { white } \\
\text { black } \\
\text { other }\end{array}$ & $\begin{array}{l}61 \\
280 \\
17 \\
7 \\
1\end{array}$ & $\begin{array}{l}45 \\
259 \\
- \\
- \\
5\end{array}$ & 12 & 4 \\
\hline Totals & 366 & 309 & 12 & 4 \\
\hline
\end{tabular}

What networks were in place that contributed to the procurement of non-local chert and quartzite raw materials? Studies of raw material use, and the occurrence of exotic raw materials, in Northeast Texas (see Bruseth and Perttula 1981; Perttula and Bruseth 1995) have shown that variations in the materials that were used changed through time, perhaps hinting at how different groups interacted with each other during their history.

The concept of stone-tipped projectiles needs to be examined closely in areas like this part of the Sabine River basin where suitable stone is not readily available. Studies have shown that the main reason stone projectiles are used is that they are more efficient killing weapons of large game (Ellis 1997). Ellis (1997) cites ethnographic data that supports the direct association between stone-tipped projectiles and the hunting of large game, with bone and wood tips used for other (and smaller) game. Perhaps this relationship may explain the drastic decline in the use of stone artifacts among later (after ca. A.D. 1300) Caddo groups, as they may have shifted from exploitation of large game to an agricultural way of life supplemented with smaller game. At the Redwine site, for example, only $5 \%$ of the artifacts were lithic artifacts, and the majority of the projectile points came from burials, not in domestic contexts. It would also be interesting to determine if there is any correlation between the frequency of stone arrow points on Caddo sites and the frequency of bone temper in pottery vessels. If arrow points were used only to take large game (with deer being the main large animal), a decrease in stone tips could have caused a significant reduction in the amount of bone available for pottery temper, since small animals or birds would not have provided much useable bone.

\section{Animal Bone}

There are 894 small bits and pieces of animal bone collected from Feature I and 2 (see Table 4). Other than this tabulation, the fragmented animal bone pieces have not been further studied at this time. There were no obvious fish bones noted in the remains, which is not surprising given the small pools of water on Auburn Creek that only support small perch and are too swift for mussels. 


\section{Floral Remains, by Phil Dering}

The analysis of the floral remains from the single flotation sample (Feature 1) from the Wolf site followed standard archeobotanical laboratory procedures. The flotation sample matrix is passed through a nested set of screens of $4 \mathrm{~mm}, 2 \mathrm{~mm}$, and $0.45 \mathrm{~mm}$ mesh and examined for charred materials, which are then separated for identification.

Charred wood caught on the $4 \mathrm{~mm}$ and $2 \mathrm{~mm}$ mesh screens was separated for weighing, counting, and identification. Carbonized wood from these screens was separated in a grab sample and identified; smaller pieces are seldom identifiable. The material caught on all of the sieve levels, including the bottom pan, was scanned for floral parts, fruits, and seeds. The carbonized macro-botanical samples collected from excavation screens were sorted and identified. Identification of carbonized wood was accomplished by using the snap technique, examining them at 8 to 45 magnifications with a hand lens or a binocular dissecting microscope, and comparing them to samples in the Texas A\&M University archeobotanical herbarium. Any seed identifications were made using seed manuals and reference collections at Texas A\&M University.

The Feature 1 flotation results are presented in Table 8. The charred plant remains from the feature suggest that the Wolf site was a settlement that practiced maize production, but still emphasized wild plant gathering. The nut to wood ratio (by weight) is 2.7 , which indicates that at this site nut processing was practiced in a fairly intensive manner. At many sites where maize abundance and ubiquity is high, nut to wood ratios are lower than 2.0. More paleobotanical data from Caddo sites are needed.

Table 8. Plant remains from Feature 1 at the Wolf site (41SM195).

\begin{tabular}{lllll}
\hline Name & Vernacular & Part & Count* & Weight $(\mathrm{g})$ \\
\cline { 1 - 2 } Carya sp. & Hickory & nut fragment & 227 & 22.8 \\
Carya sp. & Hickory & wood & 3 & 0.2 \\
Carya illinoiensis & Pecan & nut fragment & 1 & 0.1 \\
Zea mays & Maize & kemels & 7 & 0.2 \\
Arundinaria sp. & Common cane & seed & 1 & $<0.1$ \\
Pinus sp. & Pine & wood & 3 & 0.2 \\
Quercus sp. & Oak, white oak & wood & 24 & 2.2 \\
& Anatomical group & & & \\
Indeterminate & Hardwood, insufficient & wood & 92 & 5.8 \\
& nnatomical diagnostic & & & \\
& features & & &
\end{tabular}

* counts are estimates, because charred plant remains disintegrate in storage

\section{DISCUSSION}

Although there is evidence of the Wolf site having been occupied for the past 3000 years, based on radiocarbon and OCR dates and associated artifacts, the principal occupation took place in the mid- $14^{\text {th }}$ century by prehistoric Caddo peoples. The main archeological data are from a small, but intact midden deposit, and in considering the features and artifact assemblage together, the Caddo occupation was probably a small 
homestead occupied for less than 50 years. The subsistence of the Caddo peoples living at the Wolf site was based on wild game, wild plant gathering (especially hickory nutshells), and some agriculture, as indicated by the presence of corn in the one flotation sample from Feature 1. This is suggestive of a shifting agriculture way of life, with groups regularly moving as soils (and other resources) became depleted. This frequent movement of peoples could explain why sites in this area are never very large or occupied for long periods of time. Rather, the archeological evidence suggests that small family groups regularly moved across the landscape as a natural way of life, with the abandonment of sites a part of that settlement process. How people move, not to mention how far and how frequently, is a defining feature of social life and cultural identity (Pauketat 2003).

Climatic events may have also played an important part in explaining why this area was evidenlly abandoned in the 1400s. Pcrhaps Caddo groups had brought their way of agricultural life into the area during good times, but were forced to move when climatic conditions would no longer support thcir way of life. Perhaps also the Caddo developed a lifestyle during a period of favorable climatc, and to maintain it when adverse conditions occurred, they were forced to seek a morc favorable location. In this sense, a site such as the Wolf site could be considered as a procurement area, with soil being the commodity sought.

This way of life by Caddo peoples could have had cultural implications in that by regularly moving, groups would often encounter other groups where ideas as well as material objects would be exchanged. However, the Wolf site artifact assemblage provides limited indications of any widespread trade, and contact was probably limited to similar groups in the region.

In comparing the Wolf site with other known Middle Caddo sites in the area, there are differences between them, particularly in the character of the pottery. A limited number of radiocarbon and OCR dates, small sample sizes, and other factors surely play an important part in these disparities, but questions do arise: could there have been different groups occupying the same region, at the same time, that followed different cultural practices? Can sites have different functions, and are these functional differences expressed in the pottery remains? Finally, can the study of the material remain from such Caddo sites help to answer any of this?

\section{ACKNOWLEDGMENTS}

A special thanks to fellow Archeological Stewards Bryan Boyd (and his wife Karen), who helped with excavations and report graphics, and Patti Haskins, who helped me with the site mapping. Also a very special appreciation to Tim Perttula, who with a very large red pen made suggestions/revisions and helped with the wording. His unselfish donation of time towards advancing the archeological study of the Caddo are largely responsible for the efforts reported here.

All funds for this project were provided by the author, and I will also take credit for any mistakes made during its course. Hopefully, these little projects, often on sites that would never have received any professional help or interest, will add some small bit of knowledge to the prehistory of this area. 


\section{REFERENCES CITED}

Bruseth, J. E. and T. K. Perttula

1981 Prehistoric Settlement Patterns at Lake Fork Reservoir. Permit Series Report 2. Texas Antiquities Committee, Austin.

Ellis, C. J.

1997 Factors Influencing the Use of Stone Projectile Tips. In Projectile Technology, edited by H. Knecht, pp. 34-74. Plenum Press, New York.

Hatherly, D. T.

1993 Soil Survey of Smith County, Texas. United States Department of Agriculture, Soil Conservation Service, in cooperation with the Texas Agricultural Experiment Station and the Texas State Soil and Water Conservation Board.

Pauketat, T. R.

2003 Resettled Farmers and the Making of a Mississippian Polity. American Antiquity 68(1):39-66.

Perttula, T. K. and J. E. Bruseth

1995 Trade and Exchange in Eastern Texas, 1100 B.C.-A.D. 800. In "Exchange in the Lower Mississippi Valley and Contiguous Areas at 1100 B.C., edited by J. Gibson. Louisiana Archaeology 17:93-121.

Rolingson, $\mathrm{M}$.

1998 Toltec Mounds and the Plum Bayou Culture: Mound D Excavations. Research Series No. 54. Arkansas Archeological Survey, Fayetteville.

Stuiver, M., P. J. Reimer, E. Bard, J. W. Beck, G. S. Burr, K. A. Hughen, B. Kromer, B. McCormac, J. van der Plicht, and M. Spurk

1998 INTCAL98 Radiocarbon Age Calibration, 24,000-0 cal BP. Radiocarbon 40(3):1041-1083.

Suhm, D. A. and E. B. Jelks (editors)

1962 Handbook of Texas Archeology: Type Descriptions. Special Publication No. 1, Texas Archeological Society, and Bulletin No. 4, Texas Memorial Museum, Austin.

Talma, A. S. and J. C. Vogel

1993 A Simplified Approach to Calibrating C14 Dates. Radiocarbon 35(2):317-322.

Walters, $\mathrm{M}$.

2001 Archaeological Investigations and Oxidizable Carbon Ratio Dates from 41RK476, Rusk County, Texas. Journal of Northeast Texas Archaeology 15:9-27.

Walters, M. and P. Haskins, with contributions by D. H. Jurney, S. E. Goldborer, and T. K. Perttula

1998 Archaeological Investigations at the Redwine Site (41SM193), Smith County, Texas. Journal of Northeast Texas Archaeology 11:1-38.

Walters, M. and P. Haskins

2000 The Bryan Hardy Site (41SM55), Smith County, Texas. Journal of Northeast Texas Archaeology 12:1-26. 